胆囊小動脈血栓が原因と考えられた

無石性非炎症性胆囊穿孔の 1 例

\begin{tabular}{|c|c|c|c|}
\hline & 野厚生緿 & 合病院夕 & \\
\hline 高橋 孝行 & 三鍋 & 俊春 & 森 \\
\hline 棚橋達一郎 & 奈良 & 圭司 & \\
\hline & 京医科大 & 第 2 疤 & \\
\hline & 井 & 壽 & \\
\hline
\end{tabular}

\title{
A CASE REPORT OF PERFORATION OF THE ACALCULOUS GALLBLADDER OCCURING FROM THE THROMBOSIS OF CYSTIC ARTERY
}

Takayuki TAKAHASHI, Toshiharu MINABE, Toshio MORI, Tatsuichiro TANAHASHI and Keiji NARA

Department of Surgery, Sano Kosei General Hospital

\section{Toshiharu ISHII}

The Second Department of Pathology, Tokyo Medical College

索引用語：無石性胆囊穿孔, 胆襄動脈血栓, 特発性胆重穿孔

はじめに

胆囊穿孔は，その原因の大半が結石を伴う胆囊炎で あり，しばしば胆汁性腹膜炎をきたし，急性腹症の 1 疾患として早期診断执よび外科的治療が必要とされ る. また無石性で资症所見のない穿孔症例はまれで， 診断技術の発達した今日でも術前に診断することは困 難である.

今回われわれは無石性で胆囊炎を伴わず，胆囊小動 脈の血栓が原因と考劣られる非常にまれな胆囊穿孔の 1 例を経験したので, 若干の文献的考察を加え報告す る.

患者：56歳，男性.

\section{症例}

主訴：上腹部痛。

既往歴：28歳時に胃けいれんの診断にて保存的治療 を受けた。

家族歴：特記すべきことはない.

現病歴：昭和63年 3 月 22 日午前 4 時ごろ, 睡眠中突 然の上腹部痛が出現した。嘔気, 嘔吐はなかったが, 心窩部より刺すような痛みがあり, 午前 6 時 30 分当院

$<1989$ 年 7 月 10 日受理 > 別刷請求先：高橋 孝行

干327佐野市堀米町1555 佐野厚生病院外科
救急センターを受診した。臭化ブチルスコポラミン 20 $\mathrm{mg}$ を筋注され, 内服薬も投与された. 薬剂内服後に嘔 吐し, 疼痛む軽快しないため, 午前 9 時 10 分再度当院 内科を受診した。ペンタゾシン $30 \mathrm{mg}$ を筋注されたが、 疼痛は軽快せず,当科依頼されそのまま入院となった。

入院時現症：身長 $155 \mathrm{~cm}$, 体重 $40 \mathrm{~kg}$, 栄養やや不良。 血圧 $130 / 90 \mathrm{mmHg}$ ，脈拍 $78 /$ 分，整，体温 $35.6^{\circ} \mathrm{C}$. 腹部 は視診上平坦で, 触診で腫瘤を認めず，心窩部から右 季肋部にかけて压痛が著明であった。ブルンベルグ徵 候や筋注防御は認めず，腸音は聴取可能であった。

入院時一般臨床検查所見: 末梢血検査では唃血な く, 白血球増多症を呈したが, 赤沈值の元進は軽度で あり, CRP も陰性であった。 トランスフミナーゼ值は 正常で, 胆道系酵素もほぼ正常であった。血清アミラー ゼ值は正常範囲内であり，腎機能も正常であった。便 潜血検査ではオルトトリジン法，グアヤック法とも強 陽性であった（表 1 ).

腹部単純 $\mathrm{X}$ 線写真：腹腔内遊離ガス像はなく, 腸俰 締の抎張, ガスの異常集積, 鏡面像は認められなかっ た（図 1).

内視鏡検查：鎮痛剂内服後のため粘膜の詳細は不明 であったが，胃，十二指腸球部，下行脚に明らかな潰 瘍の形成は認めなかった。 
表 1 入院時一般臨床検査

\begin{tabular}{|c|c|c|}
\hline 血液 & & AMY $103 \mathrm{IU} / \mathrm{e}$ \\
\hline WBC & 17200 & BUN $11.2 \mathrm{mg} / \mathrm{dl}$ \\
\hline RBC & $464 \times 10^{4}$ & Creat $1.0 \mathrm{mg} / \mathrm{dl}$ \\
\hline $\mathrm{Hb}$ & $14.0 \mathrm{~g} / \mathrm{dl}$ & $134 \mathrm{mEq} / \mathrm{l}$ \\
\hline Het & $47.6 \%$ & $3.7 \mathrm{mEq} / \mathrm{l}$ \\
\hline Plt & $31.8 \times 10^{4}$ & $98 \mathrm{mEq} / \mathrm{\ell}$ \\
\hline 血清 & & $\mathrm{TCH} \quad 177 \mathrm{mg} / \mathrm{l}$ \\
\hline 維蛋自 & $7.1 \mathrm{~g} / \mathrm{d} \ell$ & 中性脂肪 $76 \mathrm{mg} / \mathrm{l}$ \\
\hline Alb & $4.5 \mathrm{~g} / \mathrm{dl}$ & 赤沈値 \\
\hline GOT & $25 \mathrm{IU} / \mathrm{e}$ & $20 \mathrm{~mm}$ \\
\hline GPT & $20 \mathrm{IU} / \mathrm{l}$ & $50 \mathrm{~mm}$ \\
\hline LDH & $436 \mathrm{IU} / \ell$ & $(-)$ \\
\hline ALP & $81 \mathrm{IU} / \mathrm{l}$ & 便潜血 \\
\hline LAP & $48 \mathrm{IU} / \mathrm{l}$ & オルトトリジン \\
\hline T.Bil & $0.7 \mathrm{mg} / \mathrm{dl}$ & クアヤック H \\
\hline
\end{tabular}

図 1 腹部単純 $\mathrm{X}$ 線写真. 腹腔内遊離ガスはなく, 镜 面像も認められなかった。

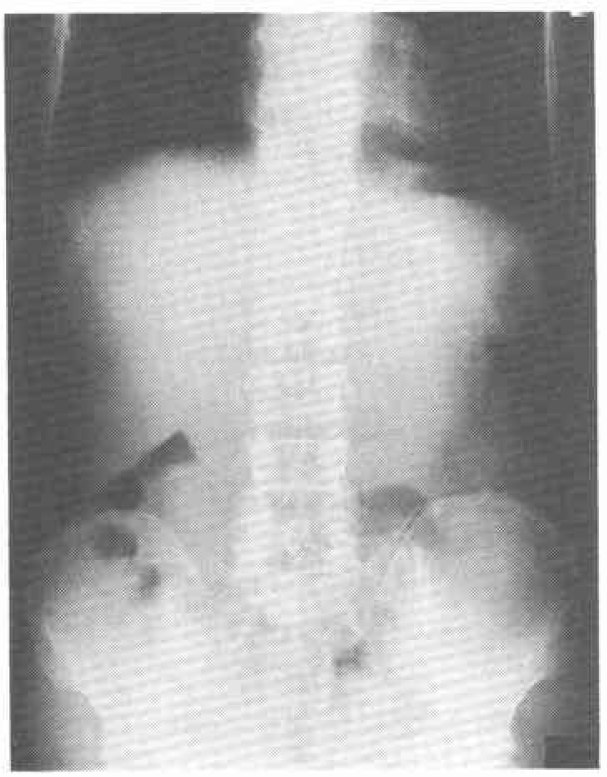

腹部超音波検査：午前 10 時 30 分と，午後 4 時 50 分の 2 回検查を施行した。初回の検査では胆囊の腫大や胆 集壁の肥厚は認めず，胆囊内に結石や胆泥も認めな かったまた肝内胆管の拡張もなく，膵管の走行も正 常であった。 2 回目の検査では, 初回時に認めなかっ た腹水が膵体部の前面に少量貯留していた，胆震には 異常所見を認めなかった（図 2).

以上の諸検査終了時に打いて，原疾患の確定診断は つかなかった。しかし超音波検査で腹水の貯留を認め,
図 2 腹部超音波検査. 左：初回検査時（午前 9 時 30 分), 胆亯の腫大や壁の肥厚は認めず, 胆雯内結石や 胆泥もなかった. 右： 2 回目 (午後 4 時 50 分), 膵体 部前面に腹水が少量貯留していた（矢印）が，胆孁 に異常所見を認めなかった。
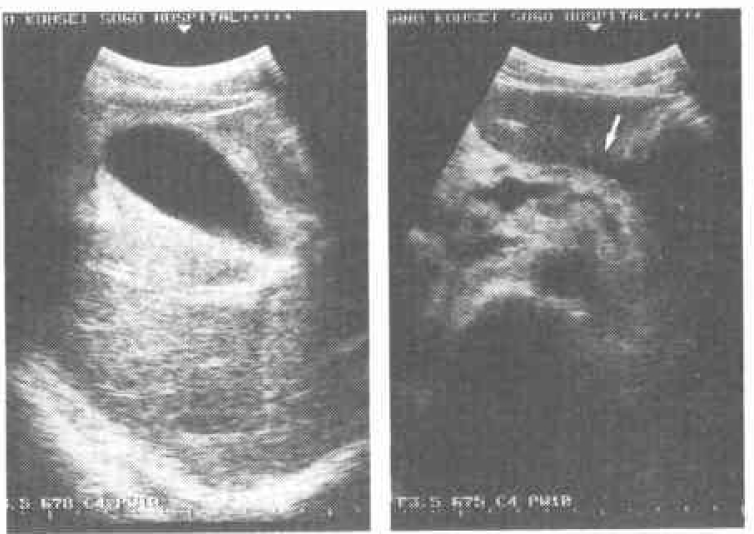

図 3 開腹時所見。胆襄体底部肝床寄りの漿膜に, 暗 褐色の胆汁貯留部があり,同部を外科ゾンデで示す.

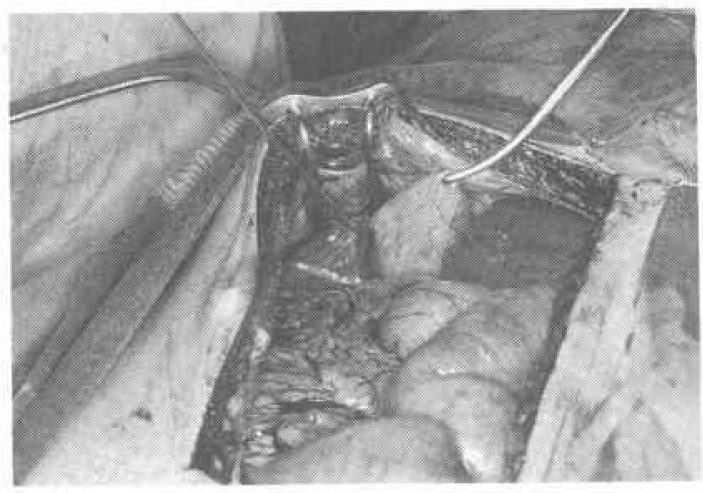

時間の経過とともに右季助部がやや膨隆し, 筋性防御 め出現してきたため, 発症14時間後の午後 6 時に, 緊 急開腹術を行った。

手術所見：上腹部正中切開にて開腹すると, 肝下面 に胆汁の貯留がみられた。胃, 十二指腸, 肝十二指腸 間膜に病巣を検索するす異常は認められなかった。左 横隔膜下，ダグラス窩に腹水や胆汁の貯留は認めな かった，胆囊は腫大しておらず，炎症所見はなかった が，体底部肝床寄りの漿膜に暗褐色に変色した胆汁貯 留部があり, 用手圧迫により胆汁の漏出を認めた。 図 3では外科ゾンデの先端が胆囊の胆汁漏出部を示して いる. 以上より胆囊穿孔による胆汁性腹膜炎と診断し, 胆囊摘出術を施行した。胆囊管より胆道造影を行うも, 
胆管の払張や狭窄, 結石などは認めなかった。再度腹 腔内を検索すると，両側の腎が下極で癒合しており馬 蹄腎を合併していた。他に異常を認めず，腹腔内を温 生理食塩液で洗浄した後, 右季助部からモリンン窩に ドレーンを留置し，手術を終了した。

切除標本：胆襄漿膜面に炎症所見はなく, 肝床付近 の胆汁漏出部に一致して, 漿膜下に胆汁の貯留があり, 軽度に膨隆していた。内腔に結石や胆砂などは認めら れず，胆汁は清澄であった，粘膜面は体底部に大きさ 約 $0.8 \times 0.6 \mathrm{~cm}$ の暗赤褐色の変色域があり, 他はほほ 正常であった（图 4 ).

術中採取された腹腔内漏出胆汁, 胆震内胆汁は培養 検查にて細菌は検出されなかった。

病理組織標本：胆囊底部の一部に, 粘膜下層の出血 を認め, この部の粘膜のみならず，粘膜下層の結合組 織扣よび筋層もはとんど消失していた，残存する粘膜

眼 4 切除標本. 胆囊体底部粘膜に暗赤褐色の変色域 （矢印）があった。

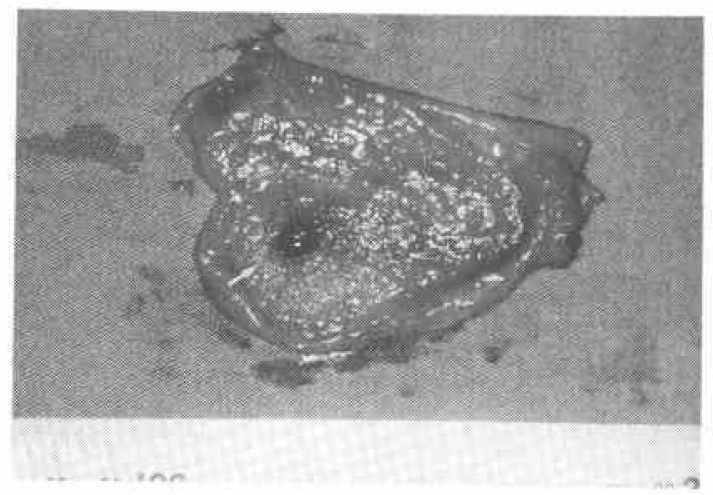

図 5 病理組織。粘膜下層の小動脈内腔は, フィブリ ン，赤血球から成る新鮮血栓により完全に閉塞して いた.（H.E. 染色, $\times 5$ )

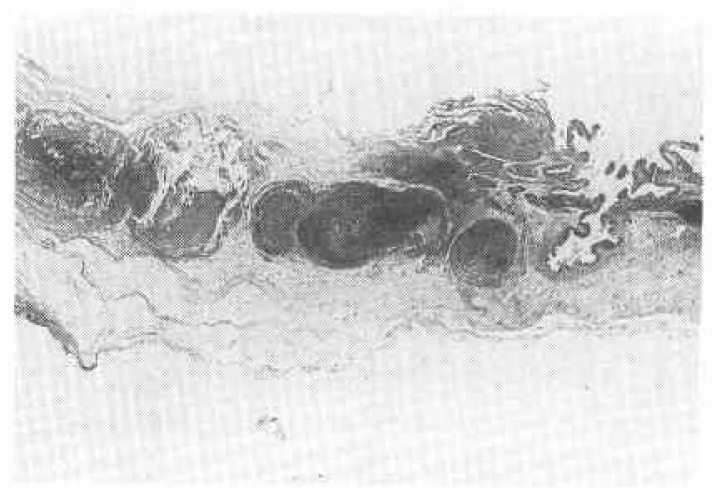

下層には少数の小動脈断面がみられるが，内腔はフィ ブリン, 赤血球から成る新鮮血栓により完全に閉塞し ており，血栓症と考えられた。この動脈に隣接する墏 膜下の踈性結合織は, 高度の浮腫により肥厚するとと もに，結合織間の間吵は著しく眯開していた。記の 病変部以外の粘膜には, 胆霟炎などの異常所見は明ら かでなかった（図 5).

術後経過：術直後より胃ソンデから胃液の流出が多 く，血液の混入をみたため，ストレス潰湯を疑い， $\mathrm{H}_{2}$ プロッカーの使用を術後 3 日目より開始した。術後 4 日目に胃ゾンデと腹腔ドレーンを抜去し，経口摄取を 始め, 20日目に退院した。術後 2 週間目の内視鏡検査 では軽度の胃炎の所見だけであった。

考察

胆石症, 胆衰炎は消化器外科領域において頻度の高 い疾患であるが，胆表穿孔例は比較的少なく，その頻 度は $3 \sim 10 \%$ とされ，胆石症が中年の肥満女性に多い のに対して，穿孔例では男女の差がなく，高龄者に多 いとされている゙.

胆要穿孔の病型分類は, Niemeier ${ }^{2}$ によるものが知 られて拈り，多くの文献は Niemeier 分類あるいはそ の亜型によっている。それによると，

(1) chronic perforation (瘦孔形成)

(2) subacute perforation (膿場形成)

(3) acute perforation (沉発性腹膜炎)

の 3 型に分けられるが，一般には（1）や（2）と区 別して（3）の開放性穿孔を胆贯穿孔として扱ってお ク，その頻度はさらに低いものとなる。

本症例は上記分類の（3）にあたり, 外科的緊急処 置を要する，発症から手術までの時間経過が14時間と 短かったため，限局性腹膜炎のみにとどまったと考兄 られる。

胆軎穿孔報告例は基礎疾患に胆石症, 胆襄炎を有す るものが大部分であり，無石性で胆覀炎を伴わず，胆 汁培盖で陰性例は非常にまれである．われわれの検索 しえた範囲で，いわゆる “特発性胆震穿孔” 報告例了) 6) は，わずか 9 例であり，本症例のような血栓症を含め ても11例である. 万ち 2 例は 1 歳と 5 歳の小児であり, 穿孔部位は頸部であった. 成人例は 56 ～92歳と高㱓で, すべて体底部に穿孔していた（表 2）。

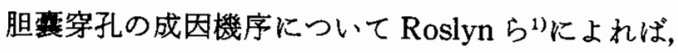
1）心血管病変が胆黹壁,特に血流の少ない底部に虚血 性変化をきたし，壊死を生じる，2）ステロイド投与や 悪性疾患による免疫機能低下が急性の胆雯炎を生じ 
表 2 特発性胆襄穿孔本邦報告例（血栓症を含む）

\begin{tabular}{|c|c|c|c|c|c|c|c|}
\hline 症峢 & 報告者 & 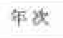 & 年部 & 性 & 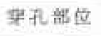 & 运因 & 柜福 \\
\hline 1 & 管 & 1935 & 60 歳 & 男 & 不明 & 特発珄 & 生 \\
\hline 2 & 河野 & 1941 & 5 歳 & 男 & 類部 & 特発性 & 死 \\
\hline 3 & 斉藤 & 1967 & 1 歳 & 男 & 䫐 部 & 特発珄 & 死 \\
\hline 4 & 森若(国立别拊) & 1978 & 75 歳 & 男 & 不明 & 血栓 & 生 \\
\hline 5 & 中谷(国位是) & 1979 & 61 葴 & 男 & 不明 & 特発性 & 生 \\
\hline 6 & 小林(沼津市立) & 1981 & 59歳 & 男 & 底部 & 特発性 & 生 \\
\hline 7 & 羽子田(大宮赤十字) & 1985 & 63 歳 & 男 & 体底部 & 特発性 & 生 \\
\hline 8 & 松羍(都立畦東) & 1985 & 66 歳 & 男 & 体底部 & 特発性 & 生 \\
\hline 9 & 林（市立長浜） & 1985 & 92 嵅 & 女 & 诋部 & 特発性 & 生 \\
\hline 10 & 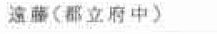 & 1987 & 65 茲 & 每: & 不明 & 井靠牛 & 生 \\
\hline 11 & 自金畄 & 1888 & 56 臷 & 9 & 体空昰 & 血精 & 生 \\
\hline
\end{tabular}

る. 3) 結石症があれば慢性胆囊炎を基礎として, 結石 が胆囊管を閉塞することにより急性炎症を起こし, 壁 の浮腫, 静脈血のうっ滞, 動脈血流の減少により壁の 虚血をきたし，壊死を生じるとしている。

本症例はステロイド投与や悪性疾患に上る免疫機能 低下はなく, 脂質代謝異常や糖尿病もなく, 心血管病 変も認めなかった。無石性で, 胆囊炎もなく, 術中所 見では明らかな原因がみつからず，腹水，胆汁の細菌 培養が陰性であり, 特発性胆囊穿孔と診断された。病 理組織学的に胆囊小動脈の血栓症と診断された。特発 性胆襄穿孔の発生機序についてて小林ら ${ }^{3)}$ は動脈硬化, さらに心血管障害による胆囊底部の虚血状態であると 推測している. 本症例は最終的に血栓症と診断された が，時間経過が長くなれば原因が不明になったかもし れない。また血栓形成の原因となる基礎疾患がなく， その意味ではよりまれとい方る。入院時検查で便潜血 が強陽性であり，消化管出血が疑われたが，血栓形成 との関係は不明である。胆囊穿孔を術前に確定診断す ることは困難であり, 腹部超音波検查, 内視鏡的逆行 性胆道造影, 経静脈的胆道造影, 胆道シンチグラフィー で穿孔を確認したという症例報告があるが，そのほと んどは有石性胆囊炎症例である7? 10). 本症例では 2 回 の超音波検査で胆㱔に異常を認めず, 少量の腹水貯留
のみを認め, 腹部症状の悪化により開腹手術を行った。 手術所見から判断して, 他の画像診断を駆使しても穿 孔を証明することは非常に困難と思われた。

無石性で胆囊炎を伴わない胆囊穿孔は，診断技術の 進歩した今日でも, 確定診断が困難である場合が多く, 臨床経過により早期に手術に踏久切ることが肝要と考 兄られた。

\section{おわりに}

胆囊小動脈血栓が原因と考兄られた無石性非炎症性 胆哓穿孔の 1 例を経験したので, 若千の文献的考察を 加光て報告した。

\section{文 献}

1) Roslyn J, Busuttil RW: Perforation of the gallbladder: A frequently mismanaged condition. Am J Surg 137:307-312, 1979

2) Niemeier OW : Acute free performation of the gallbladder. Ann Surg $99: 922-924,1934$

3）小林 進, 小沢弘侑, 鈴木昭一浮：胃出血性潰場 を続発した特発性胆霊穿孔の 1 例. 臨外 36 ： 1931-1935, 1981

4）羽根田正喜, 柿崎真吾, 篠田徳三はか：胆汁性腹膜 炎をきたした特発性胆囊穿孔の 1 例。外科診療 $27: 1240-1243,1985$

5）松曔夫, 広田英夫, 嘉和知靖之ほか：胆道疾患の 外科病理 (2). 胆囊穿孔・胆汁瘦. 臨外 40 : $1169-1171,1985$

6) 林 薰, 山口真彦, 大下 勝ほか：高齢者の特発 性胆囊穿孔の 1 治験例。滋賀医 8:131-134， 1985

7) Fleischer $\mathrm{AD}$, Muhletaler $\mathrm{CA}$, Jones $\mathrm{TB}$ : Sonographic detection of gallbladder perforation. South Med J 75:606-607, 1982

8) Morgan TR, Kogan FJ, Amberg JR et al: Demonstration of free rupture of the gallbladder by endoscopic retrograde cholangiography. Arch Surg $121: 1213,1986$

9) Lally TE, Jeffery RF: Acute rupture of the gallbladder demonstrated by intravenous cholangiography. Br J Radiol 45:466-467, 1972

10) Peck M, Viller HV, Woolfenden JM: Case report: Perforation of the gallbladder diagnosed preoperatively by nuclear imaging. Arizona Med 42:25-26, 1985 